\title{
The seismic microzonation of level 3 of Sant'Agata Fossili (northern Italy) based on a multidisciplinary approach
}

\author{
Giuseppe Di Capua ${ }^{1,}{ }^{\star}$, Massimo Compagnoni $^{2}$, Giuseppe Di Giulio ${ }^{3}$, Marco Marchetti ${ }^{1}$, \\ Giuliano Milana ${ }^{1}$, Silvia Peppoloni ${ }^{1}$, Floriana Pergalani ${ }^{2}$, Vincenzo Sapia ${ }^{1}$ \\ ${ }^{1}$ Istituto Nazionale di Geofisica e Vulcanologia, Rome, Italy \\ ${ }^{2}$ Politecnico di Milano, Dipartimento di Ingegneria Civile e Ambientale, Milan, Italy \\ ${ }^{3}$ Istituto Nazionale di Geofisica e Vulcanologia, L'Aquila, Italy
}

\section{Article history}

Received May 30, 2013; accepted November 21, 2013.

Subject classification:

Seismic microzoning, Amplification factors, Elastic acceleration response spectra, Seismic refraction, Electrical resistivity tomography, HVSR, MASW, Down-Hole, Italian Building Code.

\begin{abstract}
In this paper the results of a detailed seismic microzonation, performed at Sant'Agata Fossili (Piemonte region, northern Italy) are presented. We study the local seismic response of this small village using a level 3, that is the most accurate level following the Italian code of seismic microzonation. The activity steps consist in a gradual widening of knowledge of the different aspects of the amplification phenomena. A multidisciplinary approach has been performed to obtain the local seismic response: including a study of local geology, geophysical and geotechnical characterization of the lithologies, and numerical and experimental analyses. We finally compare the obtained elastic response spectra to the prescribed spectra of the Italian Building Code (in Italian: Norme Tecniche per le Costruzioni). Our results show the geologic and geophysical differences of the subsoil, that produce different local seismic response in terms of amplification factors and acceleration response spectra.
\end{abstract}

\section{Introduction}

The seismic hazard is usually connected to a high building vulnerability and to significant historic values of the urban centres, especially in Italy. In the activities finalized to the assessment of the local seismic hazard and the seismic risk, the geological and geophysical studies can be considered as fundamental to perform activities of prevention and reconstruction.

The aim of a study of seismic microzonation is the evaluation of the expected local seismic hazard, related to the expected seismic input and to geologic and geomorphologic properties of the subsoil. On the basis of these considerations the Piemonte region (northern Italy) has performed, in a Strategic European Project
RISKNAT (http:/ / webgis.arpa.piemonte.it/risknat/), a study of seismic microzonation for the small municipality of Sant'Agata Fossili (approximately 500 citizens). This municipality was affected by the low magnitude seismic event of April 11, 2003 ( $\mathrm{Mw}=4.9$ ), and has suffered the most damage in the epicentral area, reaching a macroseismic intensity of IMCS=VI-VII.

Starting from the recent "Indirizzi e Criteri per la Microzonazione Sismica" (Guidelines and Criteria for the Seismic Microzonation) (ICMS) [GdL MS 2008], a study of level 3 has been carried out. The level 3 consists of an accurate analysis of seismic microzonation based on geophysical surveys and numerical simulation. A multidisciplinary group has been created and the fundamental steps of the project can be summarized as follows:

(1) study of local geology;

(2) geophysical and geotechnical characterization of the lithologies;

(3) numerical and experimental analyses to evaluate the local seismic response.

In our study, the geological and geophysical heterogeneities of the subsoil properties have been defined. These heterogeneities can be considered as responsible for differences in the local seismic response, in terms of amplification factors and acceleration response spectra. Furthermore, the resulting acceleration response spectra have been compared to those proposed by the Italian seismic code "Norme Tecniche per le Costruzioni" (Technical Standards for Construction) [NTC 2008] in order to have a correct 
level of seismic protection in the project design phases.

Finally, our study gives some results in term of comparison among different geophysical techniques (noise measurements, Down-Hole tests - DH, Multichannel Analysis of Surface Waves Method-MASW, 2D array, electrical tomography).

\section{Historical and recent seismicity}

The information on the historical seismicity for Sant'Agata Fossili is scarce. This could be due to the small dimension of the municipality and therefore its little political and economical importance, that can lead to poor consideration in the historical bibliography. An alternative explanation could be the low local seismicity and consequently the absence of damages; probably all the two causes are present.

Considering the seismic events in the "Catalogo Parametrico dei Terremoti Italiani”" (Parametric Catalogue of Italian Earthquakes: GdL CPTI [2004] and Rovida et al. [2011]), the area has been hit by low energy earthquakes. Particularly the strongest and nearest events are: $1541\left(\mathrm{I}_{\mathrm{MCS} \max }=8\right), 1680\left(\mathrm{I}_{\mathrm{MCS} \max }=7\right), 1828$ $\left(\mathrm{I}_{\text {MCSmax }}=8\right)$ and $1913\left(\mathrm{I}_{\text {MCSmax }}=5\right)$ earthquakes, with magnitude between 4.9 and 5.8 , producing minor damage in the municipality (Figure 1).

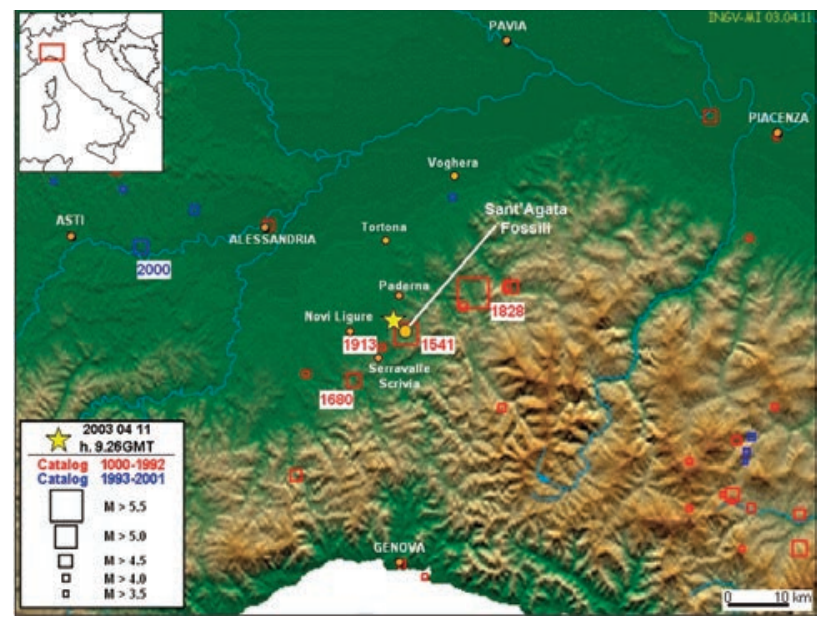

Figure 1. Location of the strongest and closest earthquakes to Sant'Agata Fossili. The orange points show the most important towns in the area closest to Sant'Agata Fossili, the squares indicate the epicentres of historical and recent earthquakes, the stars show the epicentre of the April 11, 2003 earthquake.

The recent seismicity shows events characterized by magnitude lesser than 4 and only the event of April 11, 2003 has reached magnitude producing a damage equal to IMCS=VI-VII.

\section{Experimental setting}

To investigate the subsoil, 19 pre-existent boreholes (with thicknesses between 15 and $20 \mathrm{~m}$ ) have been collected, 2 new boreholes (S1 and S2, with thick- nesses between 40 and $30 \mathrm{~m}$ ) and 2 Standard Penetration Test (SPT) have been performed, with the collection of 6 undisturbed samples to carry out the dynamic and static laboratory tests. Different geophysical investigations, as 2 Down-Hole surveys ( $\mathrm{DH}), 27$ noise measurements, 1 passive 2D array, 1 MASW, 1 seismic refraction line, 2 electrical tomography, have been conducted (Figure 2).

The investigations have pointed out a homogeneous lithological sequence, characterized by different thickness of the deposits. The sequence is generally formed by anthropic filling material or eluvial-colluvial deposits approximately $2 \mathrm{~m}$ thick over-imposed to silts, sands and

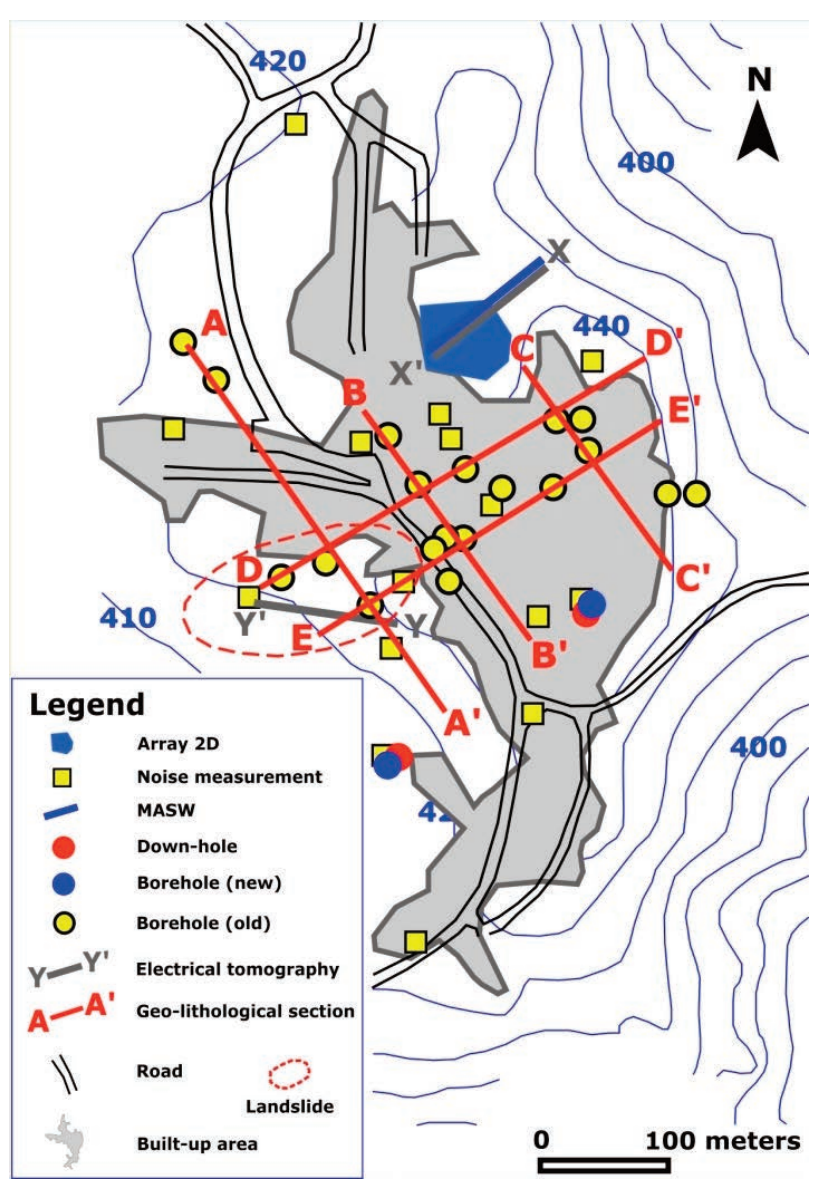

Figure 2. Location of the existing and new geotechnical and geophysical investigations.

clays. Below these deposits, marls can be considered as a geologic bedrock. In the northern-western area, gravels and cemented gravels have been found below the anthropic filling deposits or silts. In the central area an artificially stabilized landslide has been recognized.

On the 6 samples, collected in the silts sands and clays, the following geotechnical analyses have been performed: classification tests, oedometric tests, shear and resonant column tests. A series of seismic noise measurements have been carried out (Figure 2), finalized to obtain information on the resonant frequencies $\left(f_{0}\right)$. 
The average spectral ratios $\mathrm{H} / \mathrm{V}$ have been calculated [HVNSR; Nakamura 1989], and the curves are represented in Figure 3. The results show clear resonance peaks, characterized by a $\mathrm{f}_{0}$ values varying between 2.1 $\mathrm{Hz}$ and $7.4 \mathrm{~Hz}$ in the northern and western sector of Sant'Agata Fossili, whereas, in the eastern sector, the HVNSR curves show the absence of clear resonance peaks, indicating likely the absence of a strong Vs con- depth of about $40 \mathrm{~m}$ (eastern sector), whereas S2 shows an high increment of Vs at the contact between the silts and marls (depth $11 \mathrm{~m}$ ), a second velocity contrast is present in the lower part of the profile at a depth of approximately $30 \mathrm{~m}$ (western sector).

In the area (blue polygon in Figure 2) between the sectors characterized by the different behavior of Vs profile, some integrative investigations have been per-

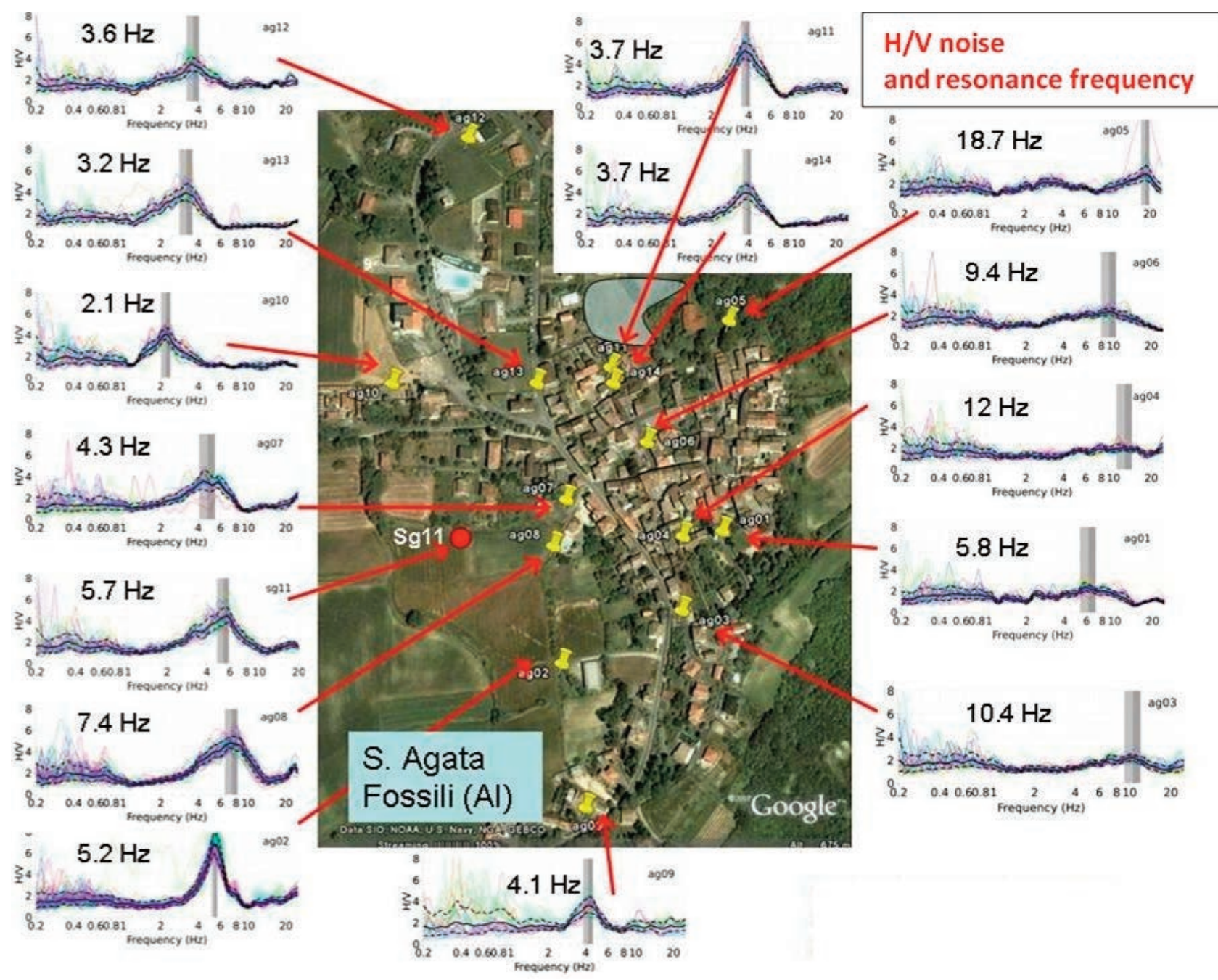

Figure 3. Location of the seismic noise measurements. The H/V curves and the resonant frequencies are reported. In the gray polygon, in the northern area, the passive measures in array configuration have been performed.

trast in the subsoil [Ibs-von Seht and Wohlenberg 1999, Delgado et al. 2000a,b, Parolai et al. 2002, BonnefoyClaudet et al. 2006, Gosar and Lenart 2010, Benjumea et al. 2011].

In these two identified sectors, two DH (S1 and S2) have been performed and the results in term of $\mathrm{Vp}$ and Vs velocity profiles are reported in Figure 4 (location in Figure 2) together with the borehole stratigraphy. The Vs velocity profiles show some differences: $S 1$ is characterized by a gradually increment of the Vs with depth, and the seismic bedrock $(\mathrm{Vs}>800 \mathrm{~m} / \mathrm{s}$ ) is reached at a formed, finalized to the study of the limit between the two sectors; particularly a 2D small-aperture array recording seismic noise and a $1 \mathrm{D}$ array of 72 geophones aimed to perform a MASW analysis [Park et al. 2005], using both active (minigun-like) and passive source to derive surface-wave dispersion curves. The HVNSR curves of the 11 stations of the $2 \mathrm{D}$ array indicate a $\mathrm{f}_{0}$ varying spatially, in a short distance, from $4 \mathrm{~Hz}$ to $6 \mathrm{~Hz}$.

The inversion of surface-wave dispersion curves, measured with the $2 \mathrm{D}$ and with the $1 \mathrm{D}$ arrays, allows to derive a Vs profile. However, the surface wave analysis 

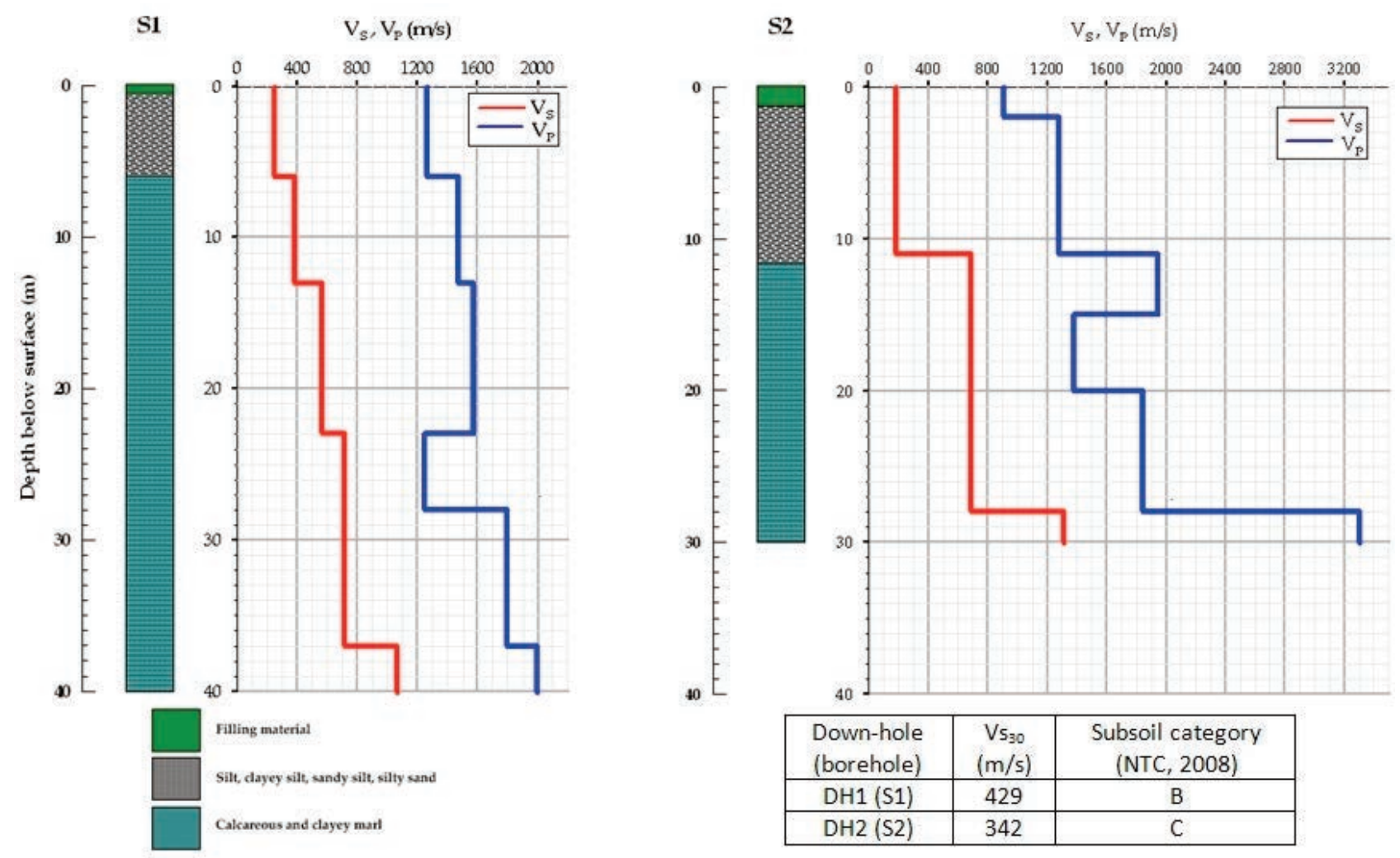

Figure 4. Vp and Vs velocity profiles obtained by Down-Holes in the S1 and S2 boreholes. The different colours identify the man-made deposits and the eluvial-colluvial deposits, the silts and clays as well as the marls.

indicate a heterogeneity of the Vs between the western and eastern sectors of the array area (Figure 5), confirming also the variability of the HVNSR curves. Summarizing, it is possible to notice from the two Vs profiles of Figure 5 a first thin layer with a Vs of about $100 \mathrm{~m} / \mathrm{s}$; then a second layer characterized by different Vs and thickness values in the two sectors: western sector of the array area with a thickness of about $10 \mathrm{~m}$ and Vs of about $340 \mathrm{~m} / \mathrm{s}$, eastern sector with a thickness of about $15 \mathrm{~m}$ and Vs of about $480 \mathrm{~m} / \mathrm{s}$ and a third layer characterized by a Vs greater than $800 \mathrm{~m} / \mathrm{s}$.

In the studied area 2 electrical tomography lines (Figure 6, location in Figure 2) have been conducted:

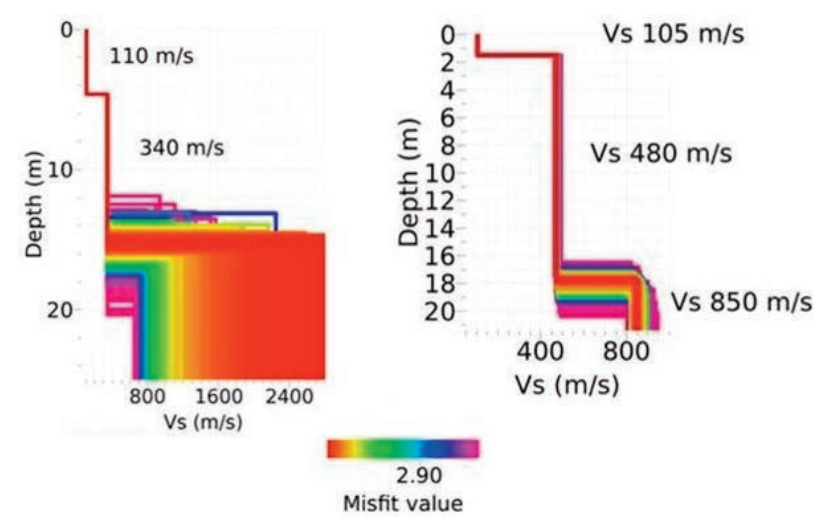

Figure 5. Inversion of surface-wave dispersion curves, measured with the $2 \mathrm{D}$ and with the $1 \mathrm{D}$ arrays. the line $\mathrm{X}$-X' shows the presence of 3 intervals of resistivity values: $5-15 \mathrm{Ohm} * \mathrm{~m}, 15-25 \mathrm{Ohm} * \mathrm{~m}$ and 25-45 $\mathrm{Ohm}^{*} \mathrm{~m}$ and the line Y-Y', performed on the stabilized landslide, shows a large resistivity contrast between surface layers (50-80 Ohm* $\mathrm{m}$ ) and the bottom layers (40 $\mathrm{Ohm} * \mathrm{~m}$ ) and indicates that the landslide thickness is about 8-10 m.

Summarizing, on the basis of borehole stratigraphies and results of geophysical measurements, we have identified 4 sectors for the studied area (Figure 7).

Sector 1 in the eastern side of the village shows nearly flat HVNSR curves. This agrees with the results of the DH-S1, which show increasing shear velocity with depth. The Vs profile does not indicate a strong velocity contrast between the anthropic filling material and silt deposits and the underlying clayey marl. The lack of a high contrast can be noticed, considering the results of the electrical tomography (thickness of 10-12 $\mathrm{m})$.

In sector 2 , the noise measurements indicated a clear resonance peak with $\mathrm{f}_{0}$ varying from 3.6 to 4.9 $\mathrm{Hz}$. The DH-S2 in this sector shows a thickness of 12 $\mathrm{m}$ for a low-velocity deposit (Vs $<200 \mathrm{~m} / \mathrm{s}$ ) overlaying a stiffer basement and the electrical tomography shows that this deposit can be correlated to a low resistivity layer (5-45 $\left.\mathrm{Ohm}^{*} \mathrm{~m}\right)$.

Sector 3 is characterized by the presence of conglomerates outcropping in the northwest portion of 


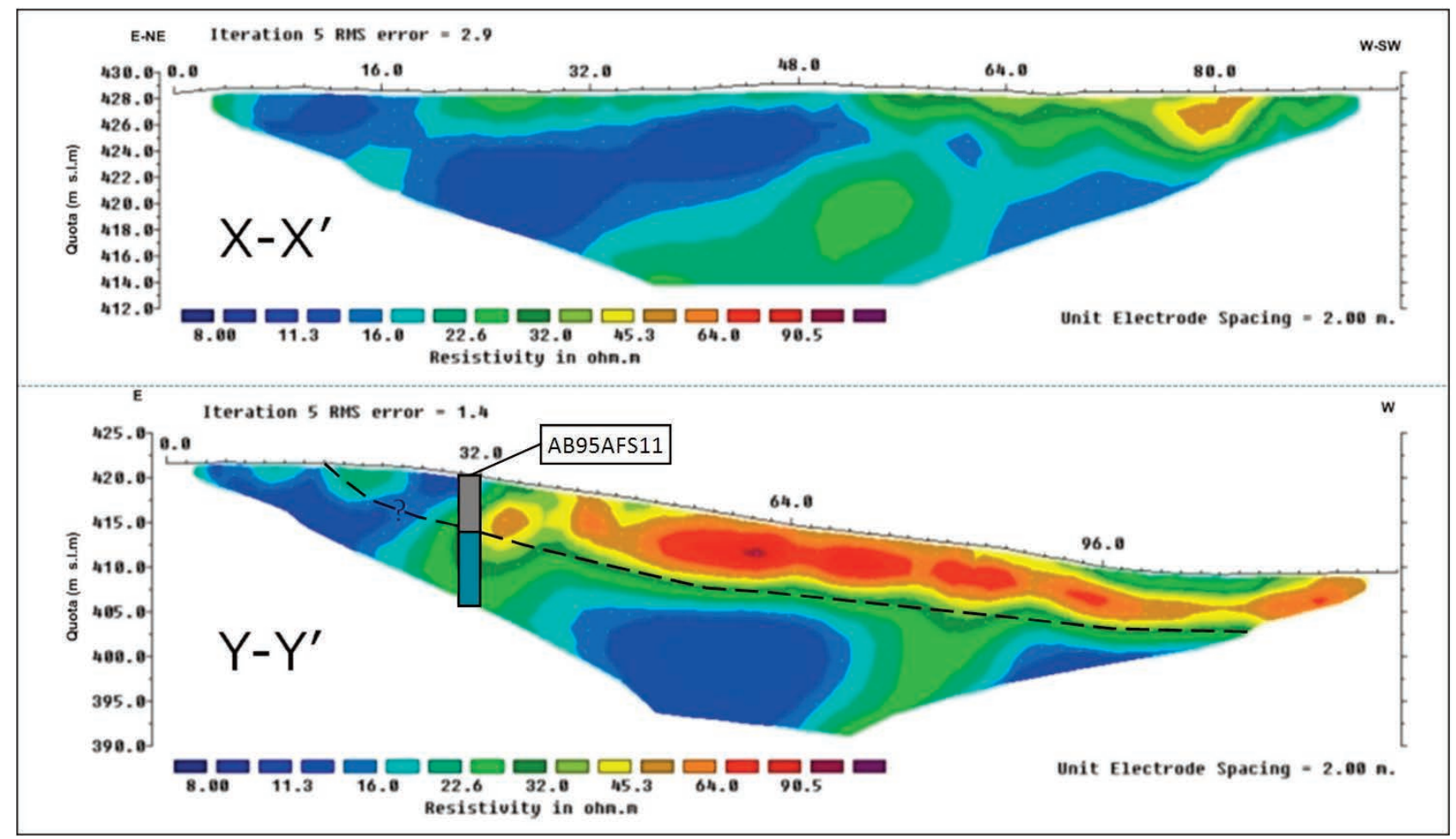

Figure 6. Results of the electric tomography for the 2 analyzed sections. Location in Figure 2. In the section Y-Y', it is traced the possible sliding surface of the landslide and is reported the stratigraphy of the closest borehole.

the village with a resonance frequency between 2.1 and $3.6 \mathrm{~Hz}$.

Sector 4 is in the central part of the village where a stabilized landslide is present. In sector 4 the two noise measurements show f0 of 7.4 and $5.2 \mathrm{~Hz}$, considering the Vs values of $200 \mathrm{~m} / \mathrm{s}$ as characteristic of the landslide material, these values allow to define the thickness of the landslide to about $8 \mathrm{~m}$. The landslide thickness is consis-

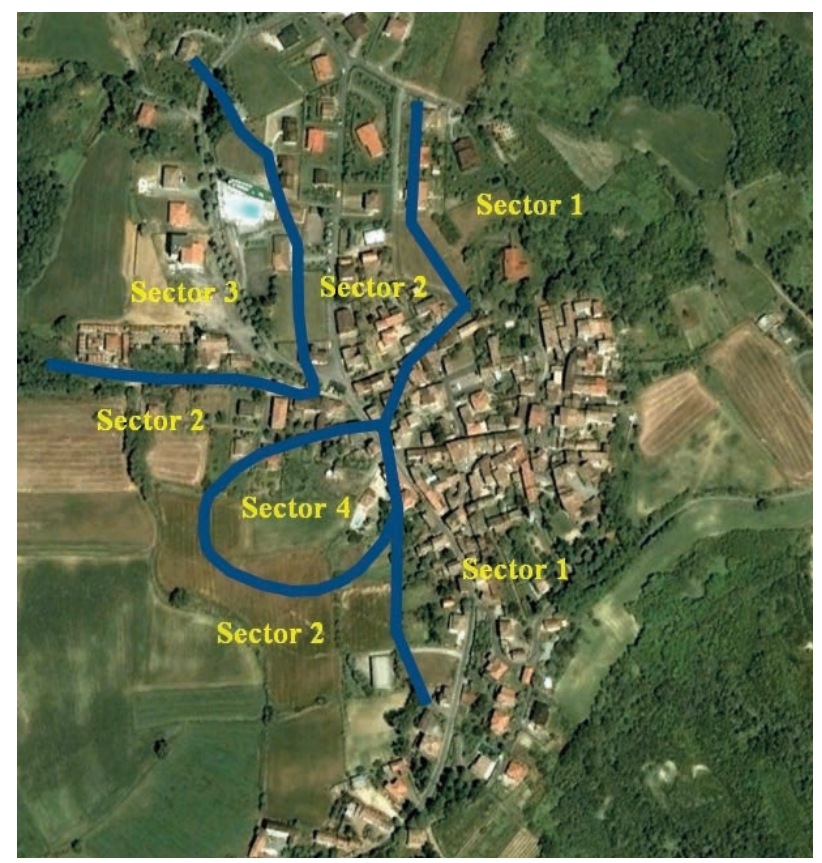

Figure 7. Areas of the municipality where groups of geophysical investigation, using different techniques, have been performed. tent with the electrical tomography data (Figure 6).

In conclusion, the comparison of the results shows a good agreement among the different investigations, allowing a valid reconstruction of the subsoil.

\section{Geolithological models and sections}

The elaboration of all data (geologic, geophysical and geotechnical) give, as mentioned, 4 main geolithological sectors (Figure 7) and different lithological models with the individuation of the geophysical characteristics of each layer. We derive several geo-lithological sections (Figure 8), used in the 1D numerical analyses of the local seismic response. The layers consist in man-made and eluvial-colluvial deposits (1-2 m) over-imposed to silts and clays and locally gravels, while the bedrock is formed by marls and, in one area (sector 3), conglomerates.

The silt and clay deposits show different characteristics in the 4 sectors:

(1) In sector 1 the silt and clay deposits have Vs of $250 \mathrm{~m} / \mathrm{s}$ (Figure 4) and a unit weight of $20 \mathrm{kN} / \mathrm{m}^{3}$. In this sector the $\mathrm{H} / \mathrm{V}$ curves are characterized by a flat behaviour (Figure 3);

(2) In sectors 2, 3 and 4 the Vs value of the deposits is $200 \mathrm{~m} / \mathrm{s}$ (Figure 4) and the unit weight is $19 \mathrm{kN} / \mathrm{m}^{3}$. The contrast of the Vs between the deposits and the bedrock is significant, as shown by the clear resonance peaks in the $\mathrm{H} / \mathrm{V}$ curves in the range $4-5 \mathrm{~Hz}$ (Figure 3).

The marls present a different behaviour of the Vs, as deduced by the results of the $\mathrm{DH}$, considering the 


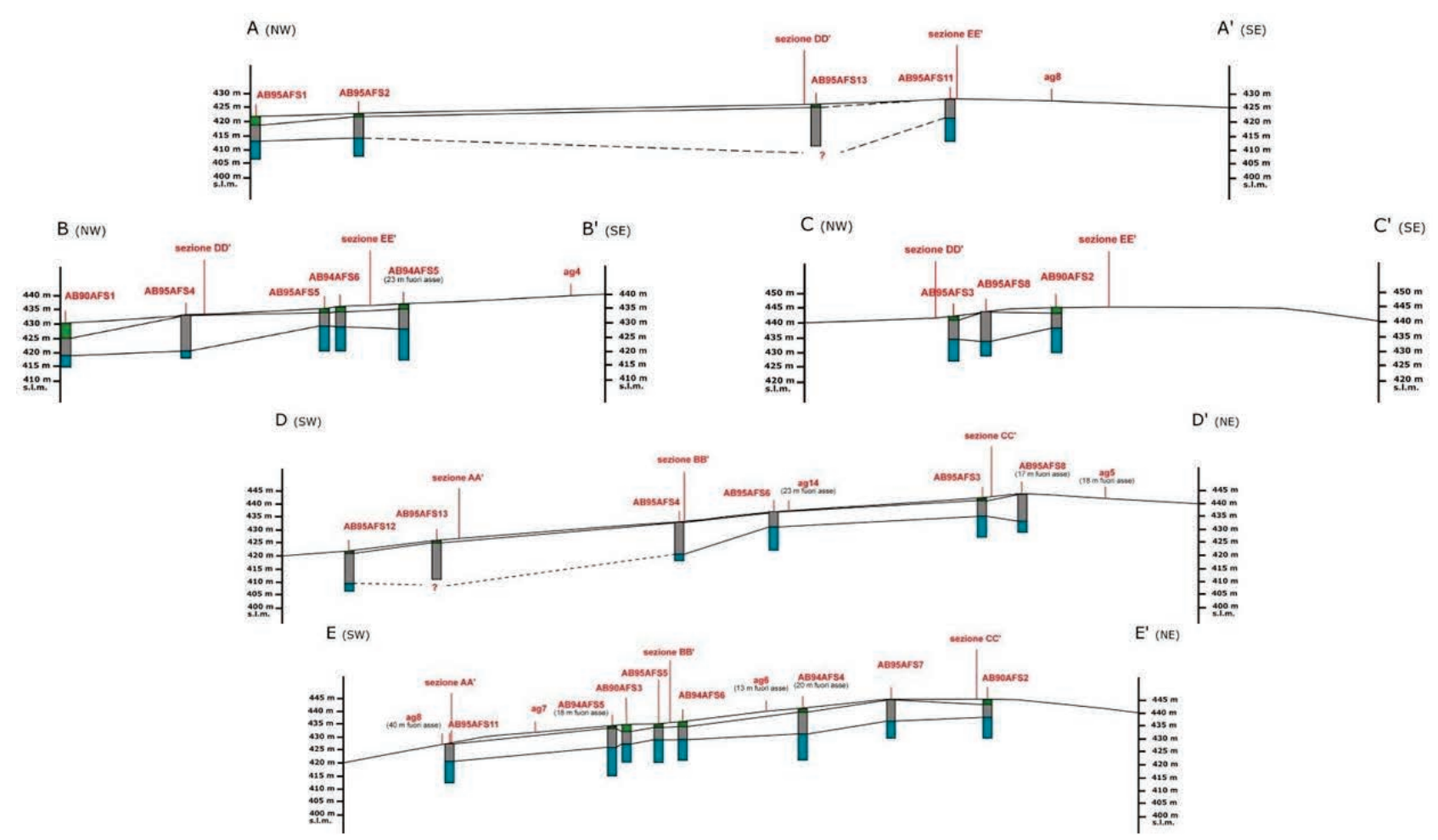

Figure 8. Geolithological sections (location in Figure 2): note the man-made and the eluvial-colluvial deposits, the silts and clays, and the geologic bedrock formed by marls.

two sectors 1 and 2 (Figure 7):

(1) In sector 1 the $\mathrm{S} 1$ survey shows that marls are characterized by a gradual increase of the Vs values; the unit weight is about $20-21 \mathrm{kN} / \mathrm{m}^{3}$. The bedrock depth is reached at about $35 \mathrm{~m}$;

(2) In sector 2 and 4 the marls are compact with a thickness of $17 \mathrm{~m}$ and $\mathrm{Vs}$ equal to $700 \mathrm{~m} / \mathrm{s}$ and a unit weight of $21 \mathrm{kN} / \mathrm{m}^{3}$ in the first layer, then the marls reach the $\mathrm{Vs}$ values of $800 \mathrm{~m} / \mathrm{s}$.

In sector 3 the sequence is characterized by silts and clays with a thickness of $3 \mathrm{~m}$, over-imposed to cemented gravels and conglomerates characterized by Vs values of $600 \mathrm{~m} / \mathrm{s}$ and unit weights about $21 \mathrm{kN} / \mathrm{m}^{3}$, over-imposed to bedrock (conglomerate).

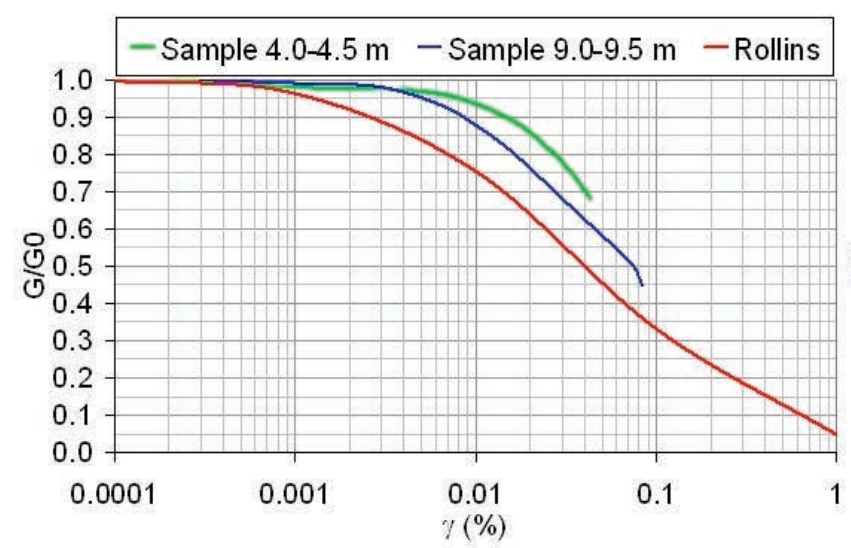

The dynamic geotechnical tests have given the curves of the behaviour of the normalized shear modulus $\left(\mathrm{G} / \mathrm{G}_{0}\right)$ and the damping ratio (D) relating to the shear stain $(\gamma \%)$ for the silt and clay deposits (Figure 9). The curves relating to the sample of depth 4.0-4.5 m are applied to the silts and clays of the sector 1 , the curves relating to the sample of depth 9.0-9.5 $\mathrm{m}$ are applied to the silts and clays of the sectors 2, 3, 4 and to marls. The curves for gravels are taken from the scientific literature [Rollins 1998].

In the sector 4 , characterized by a stabilized landslide, the subsoil model takes into account the lithological and geophysical characteristics discussed in the previous paragraph.

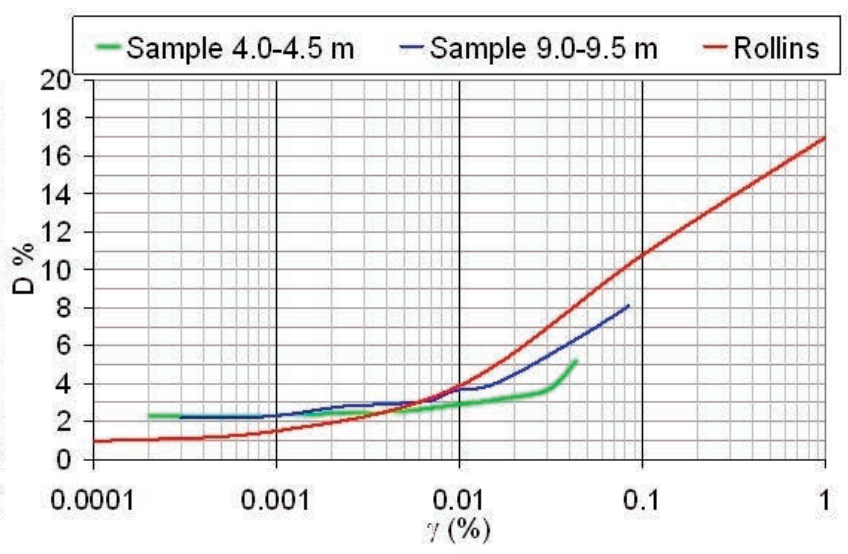

Figure 9. Behaviour of the $\mathrm{G} / \mathrm{G}_{0}$ and $\mathrm{D}$ correlating to $\gamma$. 


\section{Numerical analysis}

The numerical and experimental analyses are finalized to the evaluation of the expected seismic response in term of elastic acceleration response spectra and amplification factors, in order to derive a seismic microzonation map of level 3 [GdL MS 2008].

The numerical analyses, as prescribed by level 3 of microzoning, require realistic accelerograms and acceleration response spectra as seismic inputs. Based on the seismic hazard of Italy [GdL MPS 2004] the expected maximum acceleration values $\left(\mathrm{a}_{\max }\right)$ and the values of the spectral ordinates of the acceleration response spectra are calculated for different return periods within the national territory. The return period chosen is 475 years, considered as conventional for the local seismic response analysis. The values of $a_{\max }$ for the Piemonte region are between $0.036 \mathrm{~g}$ and $0.150 \mathrm{~g}$; for Sant'Agata Fossili the closer 4 points of the grid to the coordinates (in latitude and longitude) of the municipality have been selected: the obtained amax is the average of the 4 points with the inverse of the distance between the municipality point and the grid points and it is $0.096 \mathrm{~g}$. [GdL MPS 2004].

Recorded accelerograms have been extracted from the Database ITACA [Luzi and Sabetta 2006]: following the rules prescribed by the NTC [2008]. In particular for the selection of the seismic input we consider the:

(1) historical seismicity and seismogenetic characteristic (strike fault) [DISS Working Group 2010];

(2) couple magnitude-distance (from the data in GdL MPS 2004, the characteristic event has a magnitude between 4.5 and 5.0 and a distance between $0-10 \mathrm{~km}$ );

(3) maximum expected acceleration $(0.096 \mathrm{~g})$.

Only the accelerograms recorded on bedrock have been selected (subsoil category "A"; NTC [2008]).

The selected accelerograms have been scaled in order to have their acceleration peak similar to the expected $\mathrm{a}_{\max }$. The characteristics of the 5 accelerograms are reported in Table 1, and are namely: the code of the station, the latitude and longitude of the station, the distance of the station from the epicentre, the name of the event, the name of the station, the component of the motion, the lithology of the station, and the peak ground acceleration (PGA). The accelerograms are plotted in Figure 10.

The geologic and geomorphologic analyses of the area show the presence of horizontal layers and the presence of a ridge, so we use a mono-dimensional (1D) code [Idriss et al. 1992] for the study of the lithological amplifications and a two-dimensional (2D) code [Callerio et al. 2000] for the study of the topographic amplifications.

In the $1 \mathrm{D}$ code the soil profile is idealized as a system of homogeneous, visco-elastic sub-layers of infinite horizontal extent. The response of this system is calculated considering vertically propagating shear waves. The bedrock is considered deformable, to avoid the reflection of waves into the model, in fact a rigid layer reflects all the reflected waves from the surface, instead in the case of the deformable layer, the waves are spread into the bedrock. The code adopts the equivalent linear analysis using an iterative procedure to obtain the characteristics of the soil compatible with the effective strain in each layer in each iteration. Therefore, the process is iterative and the code works in the frequency domain, using the Fourier analysis.

On the basis of the total amount of the geological, geotechnical and geophysical data and of the 5 geo-lithological sections (Figure 8), 18 1D geolithological columns have been pointed out (Figure 11). The local seismic response has been computed for each column, using the $1 \mathrm{D}$ code and applying the 5 input accelerograms, $G / G_{0}$ and $D$ curves. The results are expressed as the average of the 5 analyses in terms of elastic acceleration response spectra (using a $5 \%$ of the critical damping) and in terms of amplification factors $\mathrm{Fa}_{0.1-0.5}$ and $\mathrm{Fa}_{0.5-1.5}$. These parameters were calculated considering the ratio of the elastic velocity

\begin{tabular}{|c|c|c|c|c|c|c|c|c|}
\hline Code & $\begin{array}{l}\text { Lat. } \\
\left({ }^{\circ}\right)\end{array}$ & $\begin{array}{l}\text { Long. } \\
\left({ }^{\circ}\right)\end{array}$ & $\begin{array}{l}\text { Epicentral distance } \\
\qquad(\mathbf{k m})\end{array}$ & Earthquake & Station & Comp. & Lithology & $\begin{array}{c}\text { PGA } \\
(\mathrm{g})\end{array}$ \\
\hline PNR & 44.877 & 7.344 & 16.0 & VAL CHISONE & Pinerolo & N-S & Rock & 0.044 \\
\hline $\mathrm{NZZ}$ & 44.782 & 8.357 & 6.0 & ZONA ALESSANDRIA & $\begin{array}{c}\text { Nizza } \\
\text { Monferrato }\end{array}$ & W-E & Rock & 0.090 \\
\hline TRT & 44.892 & 8.882 & 17.0 & OLTREPO PAVESE & Tortona & $\begin{array}{l}\text { N-S } \\
\text { W-E }\end{array}$ & $\begin{array}{l}\text { Rock } \\
\text { Rock }\end{array}$ & $\begin{array}{l}0.042 \\
0.086\end{array}$ \\
\hline
\end{tabular}

Figure 8. Geolithological sections (location in Figure 2): note the man-made and the eluvial-colluvial deposits, the silts and clays, and the geologic bedrock formed by marls. 


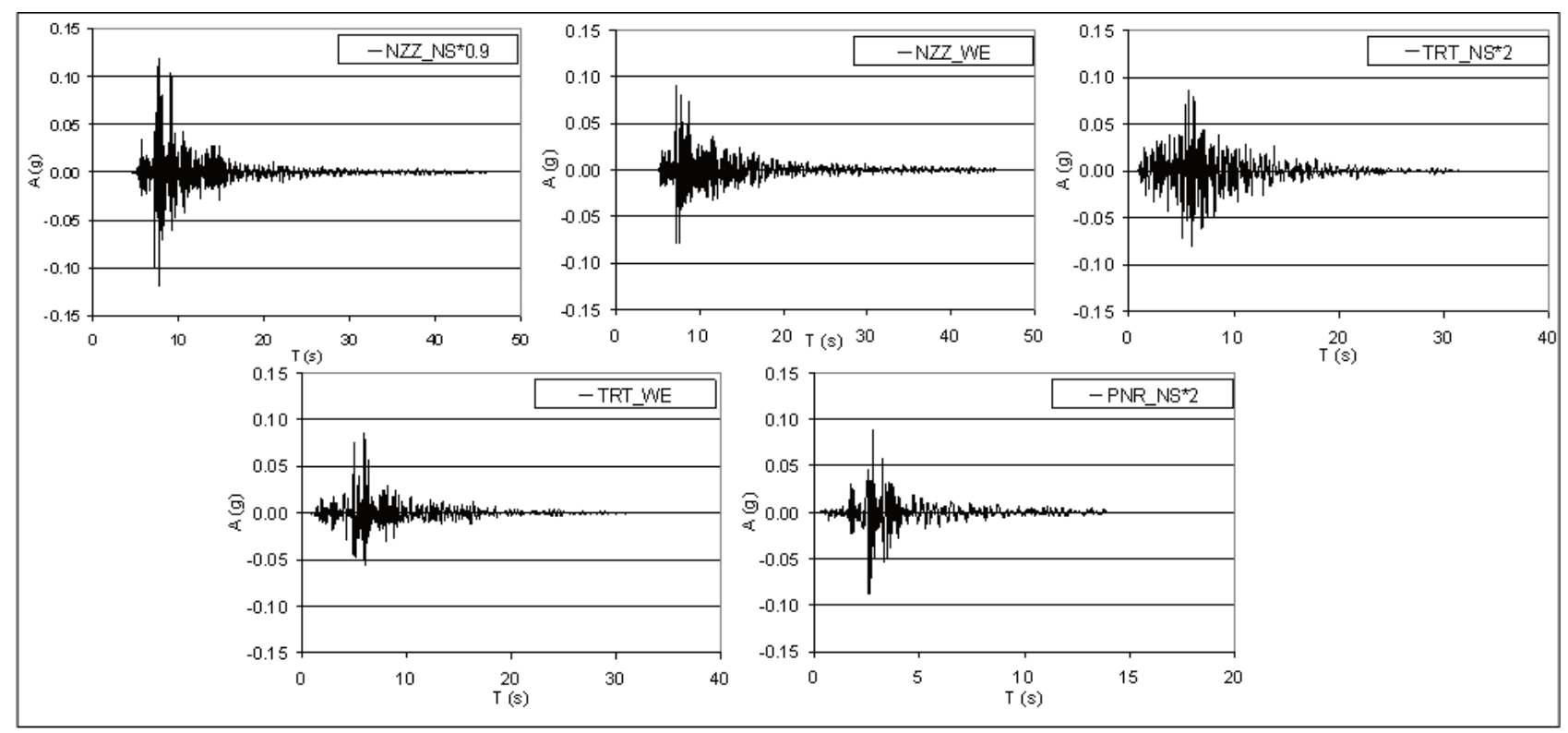

Figure 10. Accelerograms used in the numerical analyses of the local seismic response.

response spectra between the integral of output and input in the period ranges between 0.1-0.5 $\mathrm{s}$ and 0.5$1.5 \mathrm{~s}$ [Pergalani et al. 1999].

The obtained average acceleration response spectra have been compared with the response spectra pre- scribed by the national code [NTC 2008], assuming the correspondent category of subsoil for each analysed column (using the Vs30 value). To perform this comparison, the calculated spectra have been adapted to the behaviour of the code spectra (using

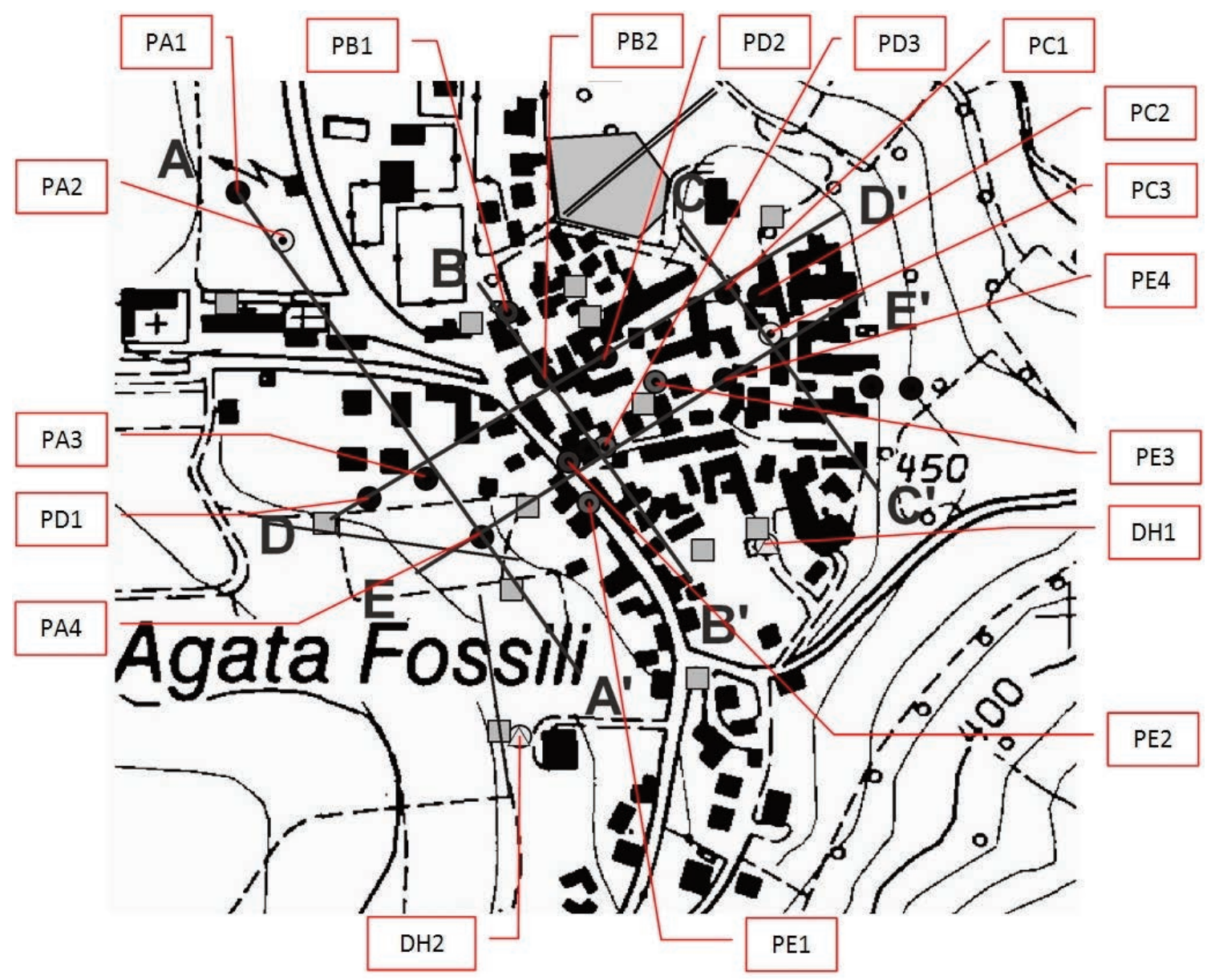

Figure 11. Location of the 18 lithostratigraphic columns used for the analyses of local seismic response 1D. 
the procedure in GdL MS [2008]) and characterized by a segment of constant spectral acceleration, a segment of constant spectral velocity and a segment of constant spectral displacement. In Figure 12 the graphs are reported. Some analysed columns show the same response spectra, so they have been joined into one graph. As shown, some national code spectra are lower than the 1D calculated spectra, particularly for low periods. The results in terms of average amplification factors are reported in Table 2. The $\mathrm{Fa}_{0.1-0.5}$ values are included between the range of 1.5-2.2 and the $\mathrm{Fa}_{0.5-1.5}$ values are included between the range of 1.1-1.6, typical values of a medium-high amplification.

The $2 \mathrm{D}$ analyses were performed using a boundary elements method. The method considers, with linear segments, only the boundary of the real structure, reducing the computational time, using the Green function and a linear elastic analysis. The structure is characterized by an elastic and homogeneous material. The code considers a continuous displacement field and works in the frequency domain applying Fourier's trans- formation to the motion equation. The topographic amplifications due to the presence of a ridge have been calculated by the application of a $2 \mathrm{D}$ code. The profile of the ridge is characterized by a width $(\mathrm{L})$ of $1700 \mathrm{~m}$ and height $(\mathrm{H})$ of $170 \mathrm{~m}$. This morphology can be classified as a pointed ridge (ratio $\mathrm{H} / \mathrm{L}$ equal to 0.1 ). In the numerical analysis a homogeneous, elastic bedrock characterized by a Vs of $800 \mathrm{~m} / \mathrm{s}$ and a unit weight of 22 $\mathrm{kN} / \mathrm{m}^{3}$ has been considered. The average response spectra and the average amplification factors do not show morphological effects.

\section{Conclusions}

The level of seismic hazard of Sant'Agata Fossili was computed for homogeneous sectors of the municipality, based on geological and geophysical investigations. The values of the amplification factors can be used in planning, for identifying the areas in which the mitigation actions are necessary and the areas suitable for new constructions. The acceleration response spectra can be used during the project design for new buildings
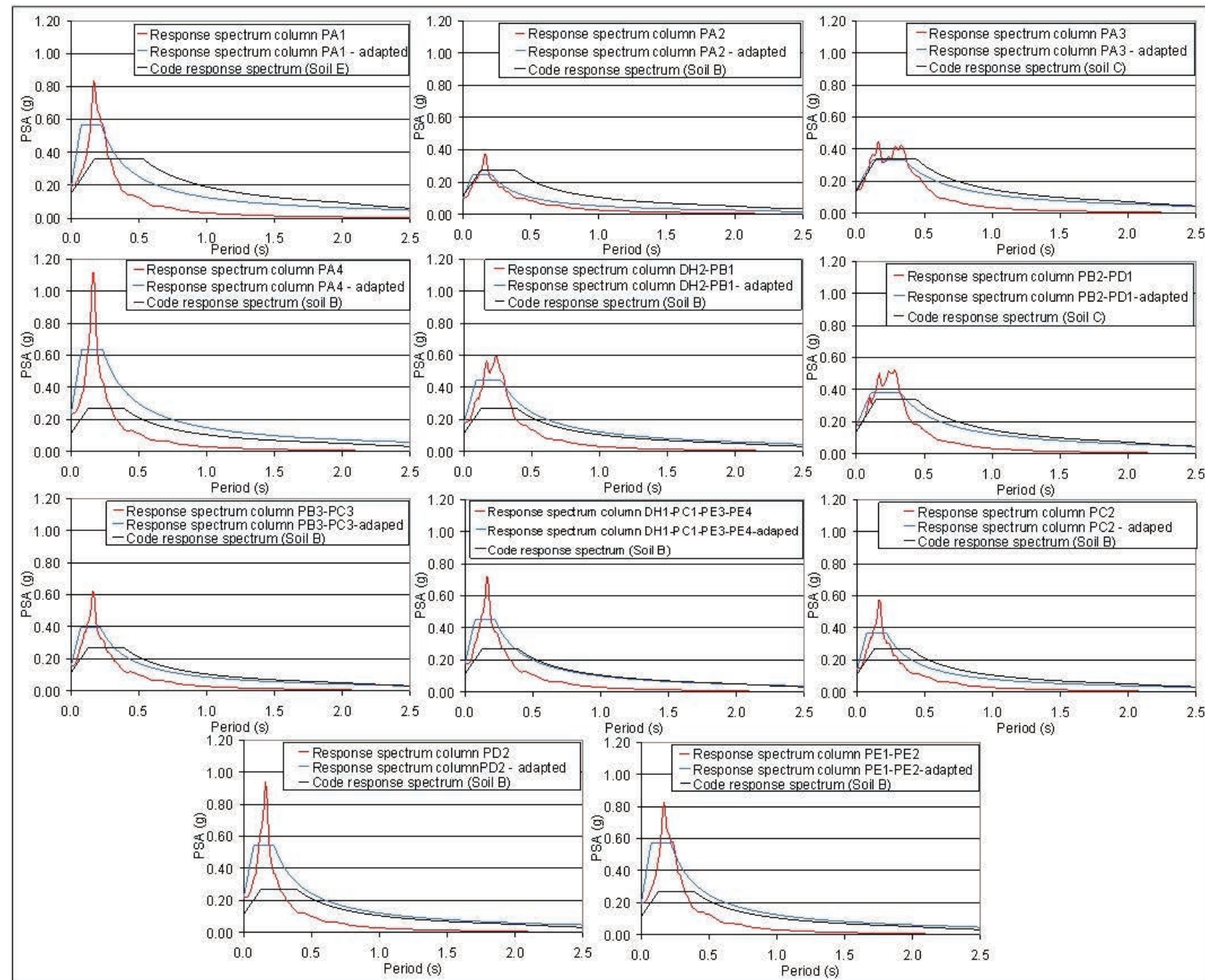

Figure 12. Acceleration response spectra of the analyzed columns (location in Figure 11) and relative national code spectra. 


\begin{tabular}{|c|c|c|c|c|c|c|c|c|c|c|c|}
\hline & PA1 & PA2 & PA3 & PA4 & $\begin{array}{l}\text { PB2 } \\
\text { PD1 }\end{array}$ & $\begin{array}{l}\text { PB3 } \\
\text { PC3 }\end{array}$ & PC2 & PD2 & $\begin{array}{l}\text { PE1 } \\
\text { PE2 }\end{array}$ & $\begin{array}{l}\text { DH1 } \\
\text { PC1 } \\
\text { PE3 } \\
\text { PE4 }\end{array}$ & $\begin{array}{c}\mathrm{DH} 2 \\
\text { PB1 }\end{array}$ \\
\hline $\mathrm{Fa} 0.1-0.5$ & 2.12 & 1.04 & 1.98 & 2.19 & 2.06 & 1.55 & 1.46 & 1.94 & 2.15 & 1.75 & 2.10 \\
\hline $\mathrm{Fa} 0.5-1.5$ & 1.26 & 1.01 & 1.55 & 1.19 & 1.40 & 1.12 & 1.10 & 1.13 & 1.27 & 1.16 & 1.36 \\
\hline
\end{tabular}

Table 2. Average amplification factors of the analyzed columns, considering the ratio of the elastic velocity response spectra between the integral of output and input in the period ranges between 0.1-0.5 $\mathrm{s}$ and 0.5-1.5 s.

and for the evaluation of the safety of existent buildings.

On the basis of the numerical and experimental analyses of the local seismic response, the seismic microzonation map of level 3 has been performed, in which the municipality has been subdivided in 4 main sectors (Figure 13).

In particular, for each sector the different response spectra are reported and the different sectors show different behaviour. In general, the results of the numerical analyses are higher than the relative national code spectra. Only in the sector 3 , in presence of the cemented gravels, the amplification phenomena are negligible.

The values of the average amplification factors $\left(\mathrm{Fa}_{0.1-0.5}\right.$ and $\left.\mathrm{Fa}_{0.5-1.5}\right)$, associated to each sector, are reported in Table 3; also in this case, the variability of the amplification factors is evident. Only in sector 3, the values of the amplification factors are equal to 1.

The HVNSR results show clear resonance peaks, characterized by $\mathrm{f}_{0}$ values between $2.1 \mathrm{~Hz}$ and $7.4 \mathrm{~Hz}$ in the northern and western sector of Sant'Agata Fossili, whereas, in the eastern sector, the HVNSR curves show the absence of clear resonance peaks. In any case, the interaction between soil resonance and building resonance effects needs further investigation, considering the height of reinforced-concrete or masonry buildings and of 2 prevailing storeys, that have likely frequencies $>7 \mathrm{~Hz}$ [NTC 2008].

In conclusion, an integrated approach based on geological and geophysical data allows investigating the heterogeneities in the subsoil properties, also consider-

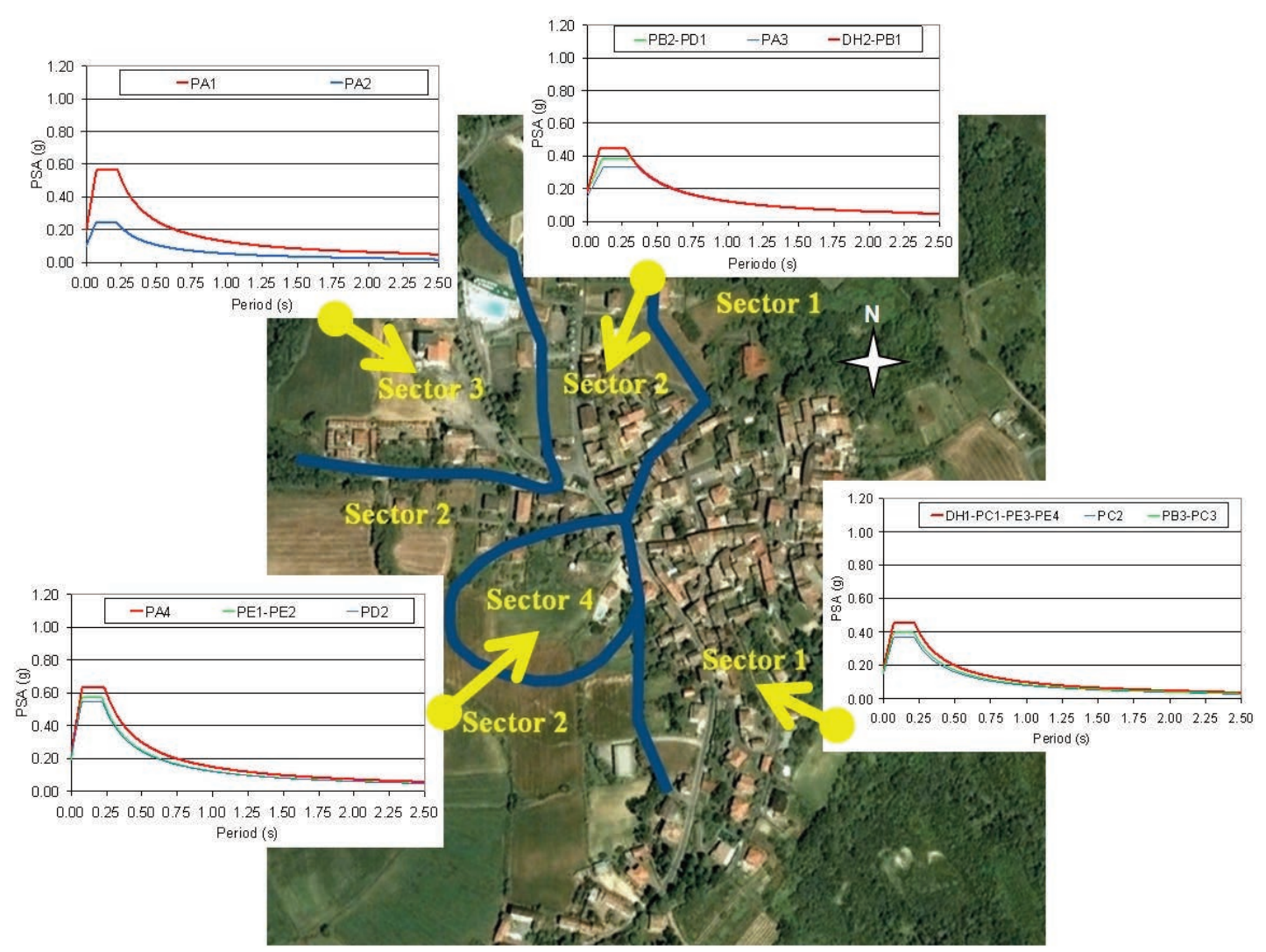

Figure 13. Seismic microzonation map of level 3 of Sant'Agata Fossili. For each sector, similar response spectra as presented in Figure 12 have been jointed in one graph. 


\begin{tabular}{lcccc}
\hline & Sector 1 & Sector 2 & Sector 3 & Sector 4 \\
\hline $\mathrm{Fa}_{0.1-0.5}$ & 1.7 & 2.1 & $2.1-1.0$ & 2.2 \\
$\mathrm{Fa}_{0.5-1.5}$ & 1.2 & 1.4 & $1.3-1.0$ & 1.2 \\
\hline
\end{tabular}

Table 3. Average amplification factors for each geolithological sector.

ing a small spatial scale of investigation. This study shows that, in urban contexts, the seismic microzonation analyses are valid and that they offer an instrument of knowledge of the territory, used for the seismic prevention of buildings, if the seismic vulnerability is known. In fact a realistic evaluation of the expected amplifications is necessary to perform the reduction of the seismic risk and the safety of the buildings.

Acknowledgements. This project has been developed by the financial contribution of Regione Piemonte and by the technical contribution of Mr. Riccardo Conte.

\section{References}

Benjumea B., A. Macau, A. Gabàs, F. Bellmunt, S. Figueras and J. Cirés (2011). Integrated geophysical profiles and $\mathrm{H} / \mathrm{V}$ microtremor measurements for subsoil characterization. Near Surface Geophysics, 9.

Bonnefoy-Claudet S., F. Cotton and P.Y. Bard (2006). The nature of noise wavefield and its applications for site effects studies. A literature review. Earth-Science Reviews, 79, 205-227.

Callerio A., V. Petrini and F. Pergalani (2000). ELCO, A program for two dimensional analyses using boundary element method, Technical report, IRRS, Milano.

Delgado J., C. Lòpez Casado, A. Estévez, J. Giner, A. Cuenca and S. Molina (2000a). Mapping soft soils in the Segura river valley (SE Spain): a case studi of microtremors as an exploration tool. Journal of Applied Geophysics (45), 19-32.

Delgado J., C. Lòpez Casado, J. Giner, A. Estévez, A. Cuenca and S. Molina (2000b). Microtremors as a geophysical exploration tool: application and limitation. Pure and applied geophysics (157), 1445-1462.

DISS Working Group (2010). Database of Individual Seismogenic Sources (DISS), Version 3.1.1: A compilation of potential sources for earthquakes larger than M 5.5 in Italy and surrounding areas, http:/ / diss.rm.ingv.it/diss/.

GdL CPTI (2004). Catalogo Parametrico dei Terremoti Italiani, versione 2004 (CPTI04). INGV, Bologna, http://emidius.mi.ingv.it/CPTI04/index.html.

GdL MPS (2004). Redazione della mappa di pericolosità sismica prevista dall'Ordinanza PCM 3274 del 20 marzo 2003. Rapporto Conclusivo per il Dipartimento della Protezione Civile, INGV, Milano-Roma, aprile 2004, 65 pp. +5 appendici, http://zonesismiche.mi.ingvit/ (in Italian).

GdL MS (2008). Indirizzi e Criteri per la Microzonazione Sismica. Conferenza delle Regioni e delle Province autonome-Dipartimento della Protezione Civile, Roma, 3 vol. e DVD (in Italian).

Gosar A. and A.Lenart (2010). Mapping the thickness of sediments in the Ljubljana Moor basin (Slovenia) using microtremors. Bulletin of earthquake engeneering (8), 501-518.

Ibs-von Seht M., and J. Wohlenberg (1999). Microtremor Measurements Used to Map Thickness of Soft Sediments. Bulletin of the Seismological Society of America, 89 (1).

Idriss I.M. and J.I. Sun (1992). User's manual for SHAKE91, A computer program for conducting equivalent linear seismic response analyses of horizontally layered soil deposits, Report of Dip. of Civil and Environmental Engineering, University of California, Davis.

Luzi L.and F. Sabetta (2006). Data base dei dati accelerometrici italiani relative al periodo 1972-2004, Istituto Nazionale di Geofisica e Vulcanologia 2006.

Nakamura Y. (1989). A method for dynamic characteristics estimation of subsurface using microtremor on the ground surface: Quarterly Report of the Railway Technical Research Institute of Japan, 30, no. 1, 25-33.

NTC (2008). Norme Tecniche per le Costruzioni, DM 14 gennaio 2008, Gazzetta Ufficiale n. 29 del 4 febbraio 2008, Supplemento Ordinario n. 30. Istituto Poligrafico e Zecca dello Stato, Roma (www.cslp.it) (in Italian).

Park C.B., R.D. Miller, N. Ryden, J. Xia and J. Ivanov (2005). Combined use of active and passive surface waves. Journal of Engineering and Environmental Geophysics (JEEG), 10, (3), 323-334.

Parolai S., P. Bormann and C. Milkereit (2002). New Relationships between Vs, Thickness of sediments, and resonance frequency calculated by the $\mathrm{H} / \mathrm{V}$ ratio of seismic noise for the Cologne area (Germany). Bulletin of the seismological society of 
America, 92 (6), 2521-2527.

Pergalani F., R. Romeo, L. Luzi, V. Petrini, A. Pugliese and T. Sanò (1999). Seismic microzoning of the area struck by Umbria-Marche (central Italy) Ms 5.9 earthquake of the 26 september 1997. Soil Dynamics and Earthquake Engineering, Elsevier Science, vol. 18, 4, 279-296.

Regione Piemonte, Progetto RISKNAT, http: / / www.risknat-alcotra.org/rna/index.cfm/b6.html (in Italian).

Rollins K.M. (1998). Shear modulus and damping relationship for gravels. Journal of Geotechnical and Geoenvironmental Engineering.

Rovida A., R. Camassi, P. Gasperini and M. Stucchi (eds.) (2011). CPTI11, the 2011 version of the Parametric Catalogue of Italian Earthquakes. Milano, Bologna, http:/ / emidius.mi.ingv.it/CPTI, doi: 10.6092/INGV.IT-CPTI11.

${ }^{\star}$ Corresponding author: Giuseppe Di Capua,

Istituto Nazionale di Geofisica e Vulcanologia, Rome, Italy; email: giuseppe.dicapua@ingv.it. 